\title{
APLIKASI REGISTRASI SEMINAR BERBASIS WEB MENGGUNAKAN QR CODE PADA UNIVERSITAS XYZ
}

\author{
Zen Munawar \\ Program Studi Manajemen Informatika \\ Politeknik LP3I Bandung \\ E-mail: munawarzen@gmail.com
}

\begin{abstract}
Abstrak: Kegiatan seminar umumnya dilakukan dilakukan oleh suatu institusi atau lembaga seperti perguruan tinggi dimana dalam pelaksaannya menghadirkan pembicara yang akan menjelaskan suatu hasil penelitian dalam bidang tertentu, selain pembicara dalam kegiatan seminar juga hadir peserta. Untuk bisa hadir di kegiatan seminar peserta diharuskan melakukan registrasi terlebih dahulu. Umumnya registrasi di lakukan dua kali sebelum dan pada saat pelaksaanaan yang sering disebut registrasi ulang, namun registrasi ulang peserta seminar sering terjadi masalah, karena masih keterbatasan panitia sehingga membutuhkan waktu cukup lama dan tidak akurat data peserta sehingga dapat menghambat kegiatan seminar. Tujuan dari penelitian ini adalah membangun aplikasi untuk registrasi ulang seminar berbasis web dengan menggunakan $\mathrm{QR}$ Code agar dapat menyelesaikan masalah tersebut yaitu tidak membutuhkan waktu yang lama pada saat proses registrasi ulang seminar dan diperoleh data yang akurat peserta seminar, yang pada akhirnya kegiatan seminar dapat berjalan dengan lancar tanpa harus membuang banyak waktu pada saat registrasi ulang seminar. Aplikasi dibuat dengan bahasa pemrograman hypertext prepocessor (PHP) dengan framework Bootstrap dan MySQL untuk database. Pembangunan aplikasi ini menggunakan metode System Development Life Cycle (SDLC). Hasil dari pengujian yang dilakukan oleh client dan user menggunakan metode blackbox telah berhasil sesuai dengan tujuan program dibuat yaitu membantu proses registrasi seminar agar lebih efisien. Adapun hasil yang di peroleh dari pembuatan aplikasi registrasi ulang seminar berbasis web menggunakan QR Code maka menghasilkan proses registrasi ulang seminar lebih cepat sehingga kegiatan seminar lebih berjalan lancar dan sukses.
\end{abstract}

Kata Kunci: Aplikasi, registrasi, seminar, QR Code

\section{Pendahuluan}

Teknologi internet yang sering diaplikasikan dalam bentuk basis Web semakin lama semakin dikembangkan untuk berbagai keperluan dan kebutuhan. Salah satunya adalah pembangunan aplikasi berbasis web. Aplikasi merupakan media penyampaian informasi secara elektronik dengan pengguna berinteraksi langsung dengan aplikasi yang dibangun (J. Philippe .B, 2003). Penerapan aplikasi dapat diterapkan pada sebuah institusi perguruan tinggi salah satunya adalah pembangun aplikasi registrasi seminar berbasis web menggunakan QR Code.

Perkembangan teknologi informasi di Era sekarang ini sangat pesat. Dengan kemajuan teknologi informasi, mengakses data atau informasi dapat berlangsung dengan cepat dan akurat. Quick Response Code (QR Code) adalah bentuk evolusi kode batang dari satu dimensi menjadi dua dimensi. Gagasan di balik pengembangan kode QR adalah keterbatasan kapasitas informasi barcode (hanya dapat menampung 20 karakter 
alfanumerik) (Tiwari. S,2016). Biaya penerapan QR Code jauh lebih murah dibandingkan dengan radio frequency identification (RFID) atau teknologi lainnya (Talip. B. A, 2018). Seminar adalah sebuah pertemuan yang bertujuan untuk membahas suatu masalah secara ilmiah. Untuk menghadiri acara seminar, beberapa seminar menggunakan tiket sebagai akses masuk. Registrasi adalah sebagai syarat keikutsertaan dalam kegiatan seminar yang digunakan untuk mendatangi atau menghadiri sebuah tempat/acara tertentu. Dalam sebuah acara seminar, peserta harus melakukan registrasi terlebih dahulu untuk mendapatkan ijin yang digunakan untuk masuk kedalam acara seminar dan registrasi tersebut masih menggunakan dalam bentuk kertas atau yang biasa disebut dengan registrasi konvensional. Permasalahan yang timbul dari registrasi konvensional dalam acara seminar tersebut yaitu tidak efisiensinya waktu karena mengharuskan peserta untuk datang ke suatu tempat yang telah ditentukan untuk registrasi seminar. Dengan menggunakan sistem QR Code akan mempercepat proses kehadiran (Hendry. R ,2017). Informasi diakses dengan menangkap sebuah kode dalam bentuk foto dengan menggunakan kamera (misalnya dengan smartphone) dan menangani kode tersebut dengan pembaca QR (Kaur. S. ,2017). Hasil yang diharapkan aplikasi dapat digunakan sebagai salah satu alat yang dapat mempermudah panitia dan peserta seminar untuk menghadiri acara seminar tersebut.

Umumnya, penyampaian informasi penyelenggaraan seminar oleh lembaga atau institusi tertentu saat ini dilakukan melalui media sosial dengan menyertakan poster/ brosur kegiatan seminar yang dilengkapi informasi tema pembahasan, pembicara yang kompeten di bidangnya, biaya, lokasi, marchandise yang didapatkan, serta contact person panitia untuk melakukan registrasi. Pada seminar tertentu disertakan juga link url untuk melakukan registrasi melalui halaman web. Namun demikian beberapa seminar juga menyediakan registrasi secara langsung di tempat pada hari pelaksanaan seminar. Proses registrasi dilakukan melalui contact person, bisa lewat aplikasi chat maupun email, mengirimkan bukti pembayaran, setelah itu mendapat undangan melalui email sebagai syarat masuk, bisa juga bukti pembayaran digunakan sebagai syarat masuk.

Kemudian sebelum memasuki area seminar dilakukan registrasi ulang untuk proses presensi peserta. Peserta juga akan mendapat sertifikat di akhir acara. Perguruan tinggi sebagai salah satu lembaga pendidikan juga turut menyelenggarakan aktivitas seminar dalam upaya menambah wawasan dan ilmu pengetahuan mahasiswa dan dosen di luar teori yang di dapat pada saat di kelas maupun melengkapi tambahan ilmu dari yang di dapat dari dosen di kelas. Tema yang dibahas umunya mengambil dari isu dan teknologi serta metode yang sedang ramai dibicarakan sebagai contoh nyata dari teori yang dijelaskan dalam materi mata kuliah. Masing - masing program studi mengadakan seminar secara rutin dengan tema dan pembicara yang berbeda setiap waktu nya. 
Aplikasi registrasi seminar berbasi web yang dilengkapi QR Code, serta menerima sertifikat melalui email. Selain itu dengan adanya aplikasi ini dapat mengurangi kesalahan rekapitulasi peserta seminar dan mempermudah panitia merekap kehadiran peserta seminar dengan scan QR Code yang ada pada tiket sehingga antrian memanjang dapat dihindari, serta sertifikat yang dibagikan sesuai dengan data peserta ataupun data kehadiran yang didapat saat scan QR Code.

Berdasarkan latar belakang yang dijelaskan di atas, dapat dirumuskan masalah sebagai berikut, pembangunan aplikasi registrasi seminar berbasis web yang dapat merekap data peserta secara online, pembangunan aplikasi registrasi seminar yang didalamnya termasuk daftar kehadiran seminar yang lebih cepat.

Seminar ini dinilai penting karena dapat menambah pengetahuan mahasiswa di luar materi mata kuliah di kampus, selain itu mengumpulkan sertifikat yang sesuai program studi yang diambil dengan jumlah tertentu merupakan salah satu syarat mahasiswa untuk mengikuti sidang Tugas Akhir. Untuk mendukung kegiatan seminar tersebut diperlukan tim panitia untuk membantu proses pendaftaran calon peserta sampai peserta memperoleh sertifikat. Selanjutnya akan disampaikan teori penunjang dalam penelitian ini.

\section{Metodologi Penelitian}

Metodologi penelitian yang digunakan dalam penelitian ini adalah dengan menggunakan model waterfall. Model waterfall menyediakan pendekatan alur hidup perangkat lunak secara berurutan yang dimulai dari analisis, desain, pengodean, dan pengujian. Analisis merupakan sebuah tahapan yang digunakan untuk menganalisis spesifikasi atau kebutuhan akan aplikasi yang akan dibangun. Sedangkan desain merupakan tahapan perantara untuk memetakan spesifikasi atau kebutuhan aplikasi yang akan dibangun.

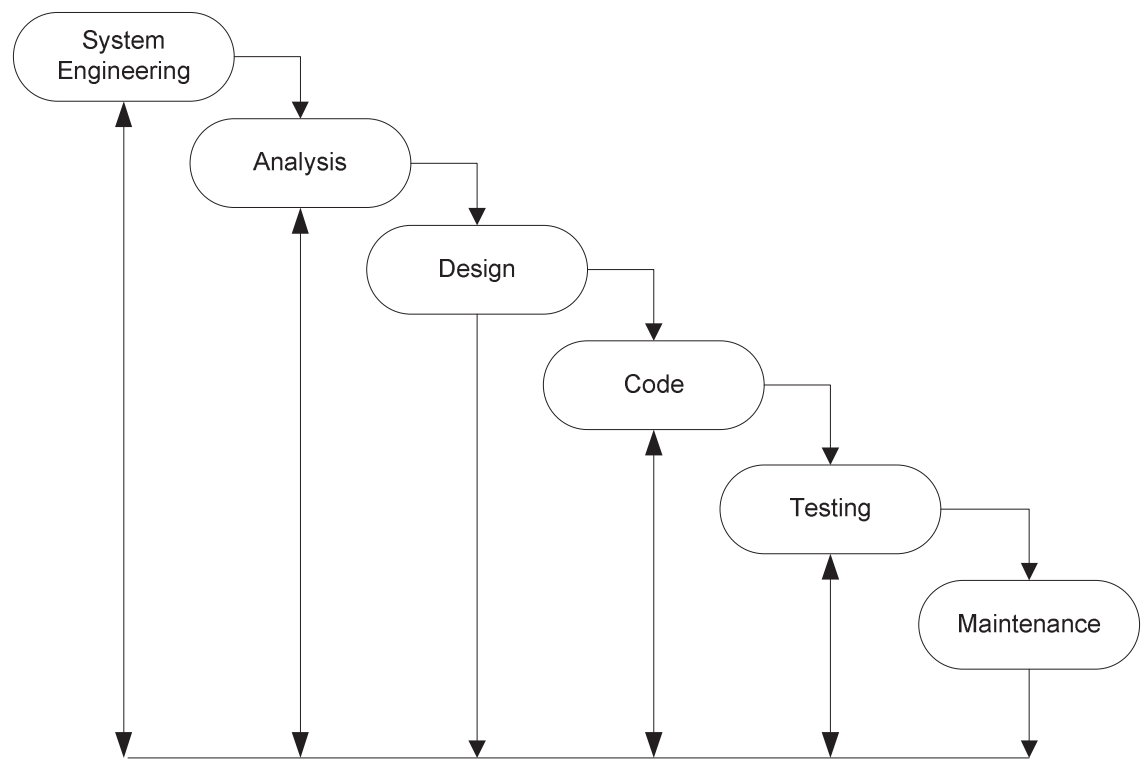

Gambar 1. Model Waterfall 
Berikut ini tahapan yang dilakukan dalam penelitian ini:

a. Pengumpulan data .

Data dikumpulkan dengan menggunakan wawancara kepada narasumber secara langsung untuk mengetahui proses sistem yang berjalan dan dokumen-dokumen yang digunakan dalam sistem yang berjalan.

b. Analisis sistem yang berjalan

Prosedur registrasi sistem yang berjalan digambarkan dengan menggunakan proses bisnis. Proses bisnis menggambarkan aliran kerja atau aktivitas dari sebuah sistem atau proses bisnis atau menu yang ada pada perangkat lunak. Kemudian akan dilakukan analisis terhadap dokumen masukan dan keluaran untuk mengetahui kebutuhan sistem usulan.

c. Analisis sistem usulan

Setelah menemukan solusi untuk sistem yang diusulkan untuk mengatasi permasalahan sistem yang berjalan, maka Sistem usulan digambarkan dengan menggunakan use case diagram. Use case diagram merupakan pemodelan untuk kelakuan dari sebuah sistem informasi yang mau dibuat (Rosa. A.S , 2015).

d. Desain sistem

Pada tahapan ini akan dilakukan perancangan layar berdasarkan kebutuhan sistem usulan, menggambarkan struktur sistem dari segi pendefinisian kelas-kelas yang akan dibuat untuk membangun sistem digambarkan dengan menggunakan class diagram. Kelas memiliki atribut dan metode atau operasi (Rosa. A.S , 2015).

e. Implementasi

Berdasarkan desain sistem yang ada akan diimplementasikan dengan menggunakan bahasa pemrograman php dan basis data MySQL.

f. Pengujian

Aplikasi yang sudah dibuat akan dilakukan pengujian apakah sudah sesuai dengan kebutuhan user atau tidak.

Pengumpulan data dilakukan untuk memperoleh dan mencatat data yang dibutuhkan untuk menyusun penelitian. Pada tahap analisis dilakukan wawancara dengan pengguna, sehingga terciptanya komunikasi antara peneliti dengan pemakai aplikasi, dengan tujuan mendapatkan informasi bagaimana sistem registrasi ulang seminar yang sedang berjalan, harapan atau keinginan pengelolaan arsip yang dapat memberikan manfaat yang dapat dirasakan tidak hanya oleh panitia namun semua yang terlibat pada kegiatan seminar. Wawancara dilakukan dengan datang langsung ketempat yang dijadikan objek penelitian, sehingga diperoleh informasi registrasi ulang seminar yang sedang berjalan, kebutuhan apa saja yang harus dipenuhi ketika membangun sebuah aplikasiregistrasi seminar, serta bagaimana tanggapan terhadap gambaran umum aplikasi yang akan dibuat.

Setelah berkomunikasi dengan pihak penyelenggara / panitia seminar, maka didapat :

1. Pengelolaan registrasi peserta seminar masih konvensional yaitu dicatat dibuku secara manual.

2. Kurang terkontrolnya data peserta yang daftar, sehingga menyebabkan pada saat pembuatan sertifikat sering terjadi kesalahan identitas peserta.

3. Terdapat kesulitan dan membutuhkan waktu yang lama ketika registrasi ulang terjadi dengan jumlah peserta yang banyak.

Tahapan penelitian dalam pembangunan aplikasi registrasi seminar berbasis web menggunakan QR Code ini ditunjukkan pada Gambar berikut: 


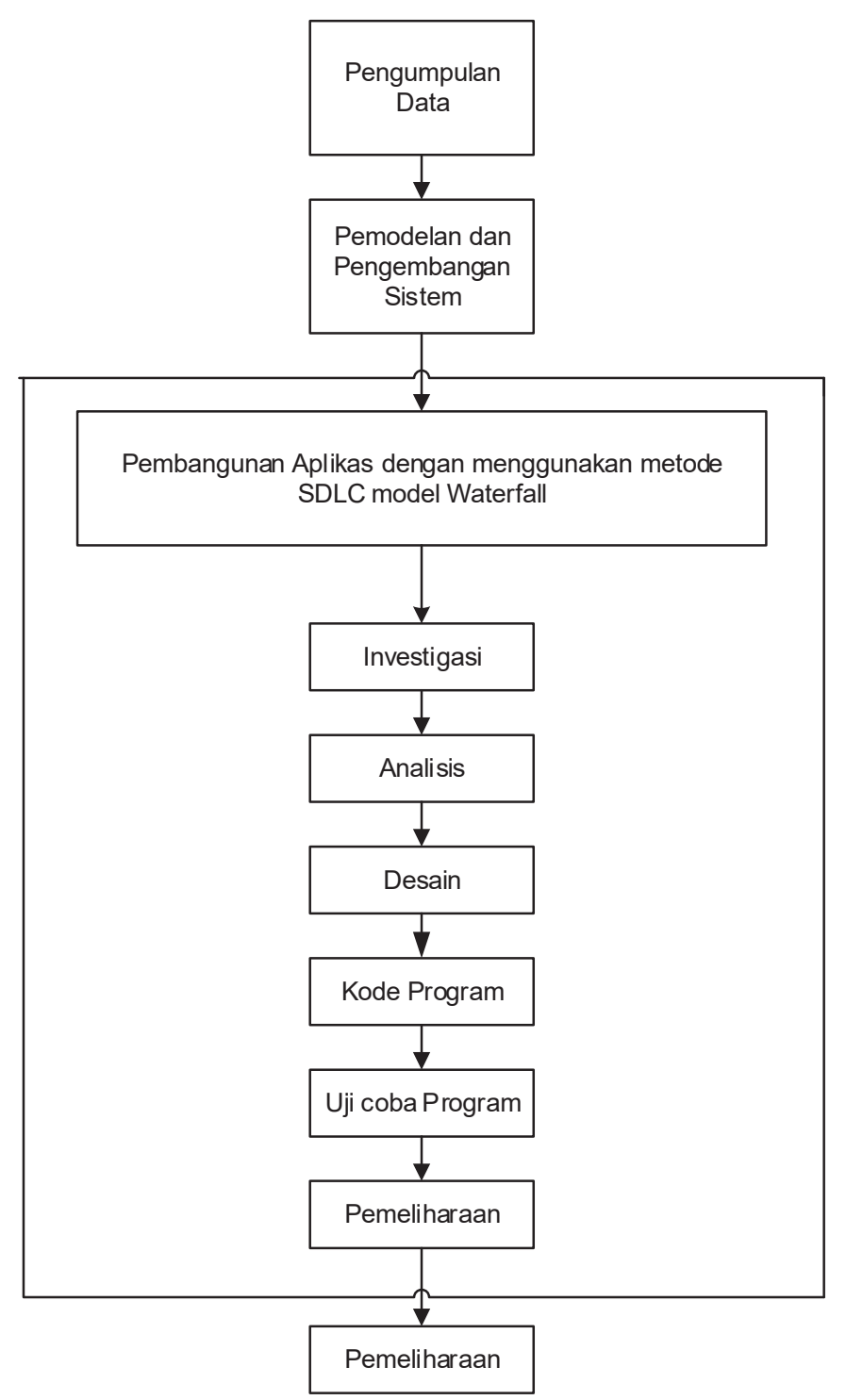

Gambar 2. Tahapan penelitian dalam pembangunan aplikasi registrasi seminar berbasis web menggunakan QR Code.

Dari hasil diatas, maka kebutuhan terhadap pembangunan aplikasi registrasi seminar terbagi jadi dua yaitu kebutuhan terhadap perangkat lunak dan perangkat keras. Untuk kebutuhan perangkat lunak dibutuhkan adanya sistem operasi, bahasa pemograman, dan database. Sedangkan untuk kebutuhan perangkat keras dibutuhkan satu buah komputer sebagai server dan juga satu buah handphone.

Desain sistem yang di butuhkan pada aplikasi pendaftaran ualng menggunakan QR Code pada kegiatan seminar yang meliputi

a. Desain Homepage

Pada halaman ini merupakan tampilan utama di web untuk pendaftaran peserta seminar.

b. Desain halaman Pendaftaran

Pada Form ini merupakan tampilan pendaftaran bagi peserta yang akan mengikuti seminar. 


\section{c. Desain Peserta}

Pada halaman ini terdapat kolom cari dan biodata merupakan tampilan biodata peserta

d. Desain Daftar hadir

Pada halaman ini merupakan daftar hadir peserta yang mengikuti seminar.

e. Desain Laporan

Pada halaman ini merupakan tampilan data laporan peserta yang mengikuti kegiatan seminar.

Pada tahap pengkodean dilakukan sesuai dengan kebutuhan sistem dan desain sistem yang telah dirancang untuk aplikasi kegiatan seminar dengan menggunakan bahasa pemrograman PHP dan My SQL dengan didukung bahasa pemrograman desain seperti javascript, css, ajax dan sebagainya sehingga tampilan dari pengkodean PHP sangat userfriendly.

Pada tahap pengujian merupakan proses akhir dari keseluruhan aplikasi yang dibuat, proses pengujian dilakukan sebagai cara menguji aplikasi yang bertujuan memperbaiki kesalahan aplikasi, sehingga dapat diperbaiki kesalahan pada aplikasi tersebut.

Proses pemeliharaan dan pengelolaan aplikasi registrasi ar menggunakan QR Code di kegiatan seminar. Pemeliharaan Perangkat lunak antara lain mencakup perangkat lunak sistem operasi, perangkat basis data, dan QR Code. Sedangkan pemeliharaan pada perangkat keras yaitu pada Personal Computer.

Pada model yang akan dikembangkan, selanjutnya perlu dilakukan validasi model, dalam hal ini disampaikan masalah apa saja yang sedang dihadapi dalam penelitian ini kemudian menyimpulkan apakah model perancangan sistem yang dibuat akan membantu mengatasi masalah yang terjadi dalam kondisi sebenarnya. Validasi dilakukan pengujian sistem yang bertujuan untuk menemukan kesalahan-kesalahan pada perangkat lunak yang diuji. Pengujian bermaksud untuk mengetahui perangkat lunak yang dibuat apakah sudah memenuhi kriteria yang sesuai dengan tujuan perancangan perangkat lunak tersebut. Pengujian yang digunakan untuk menguji sistem yang baru adalah metode pengujian black box. Pengujian black box berfokus pada persyaratan fungsional perangkat lunak dan pengujian ini berusaha menemukan kesalahan-kesalahan, berikut pengujian yang dilakukan pada : Pengujian interface, pengujian fungsi-fungsi apakah sesuai dengan prosedur, dan pengujian kinerja system.

\section{Prosedur Registrasi Seminar}

Prosedur registrasi seminar menggunakan QR code. QR Code ini di gunakan sebagai media absensi peserta yang mengikuti seminar yang berlajalan saat ini. Pada saat peserta melakukan absensi, peserta memberikan QR Code yang telah di dapatkan pada saat registrasi kepada panitia seminar untuk melakukan registrasi ulang. Selanjutnya dengan adanya QR Code sebagai media absensi pada saat registrasi ulang seminar diharapkan dapat mempercepat waktu proses registrasi ulang peserta dan mengurangi terjadinya kesalahan pada saat pengisian biodata pada sertifikat peserta yang mengikuti seminar.

\section{Perancangan}

Perancangan aplikasi registrasi seminar berbasis web menggunakan QR Code adalah perancangan struktur menu yang menggambarkan alur proses penyampaian informasi yang akan dikembangkan. Struktur menu ini dimulai dengan tampilan layar utama atau homepage, menu daftar, menu membuat QR Code, menu kateagori, menu peserta, menu 
QR Code, menu absensi dan menu rekapitulasi, di mana didalam menu ini terdapat berbagai informasi tentang absensi peserta seminar.

Berikut ini merupakan gambaran struktur dari aplikasi registrasi seminar berbasis web menggunakan QR Code pada kegiatan seminar yang akan dibuat sebagai berikut.

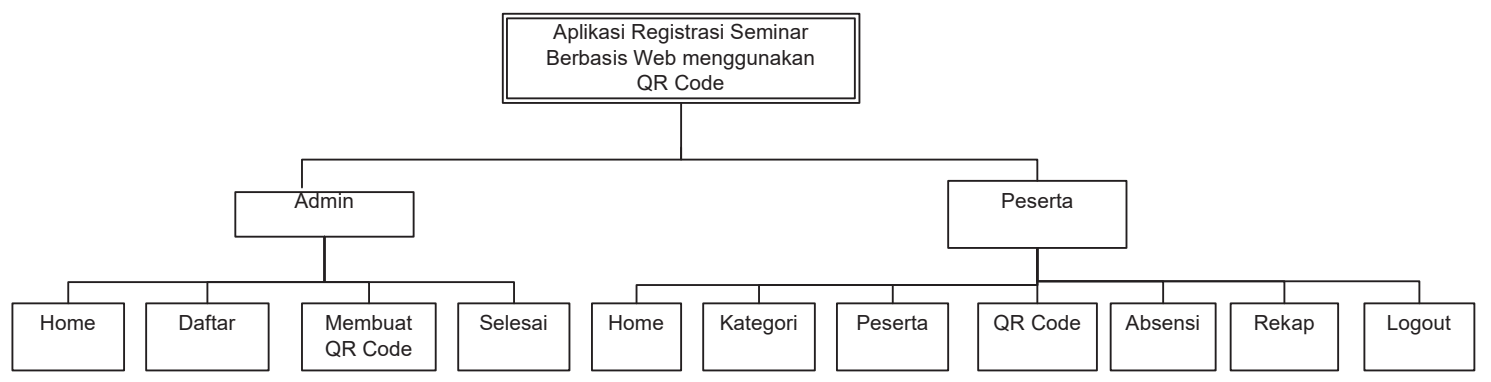

Gambar. 3. Struktur Menu Aplikasi Registrasi Seminar

\subsection{Lingkungan Aplikasi}

Lingkungan sistem merupakan perangkat-perangkat yang dapat menunjang dijalankannya aplikasi registrasi seminar berbasis web menggunakan QR Code apakah di jalankan dengan baik.

Penjelasan Menu pada aplikasi akan dijelaskan dalam bentuk tabel di bawah ini :

Tabel 1. Penjelasan menu pada aplikasi

\begin{tabular}{|l|l|l|}
\hline No & \multicolumn{1}{|c|}{ Nama Halaman } & \multicolumn{1}{c|}{ Penjelasan } \\
\hline 1 & Halaman Awal & $\begin{array}{l}\text { Menampilkan form halaman awal yang berisikan } \\
\text { form log in dan form daftar,form log in buat admin } \\
\text { dan form peserta buat peserta yang akan mendaftar } \\
\text { seminar. }\end{array}$ \\
\hline 2 & Menu home Peserta & $\begin{array}{l}\text { Tampilan awal Website sebagai petunjuk tahap } \\
\text { pendaftra yang akan di lakukan peserta yang } \\
\text { mengikuti seminar. }\end{array}$ \\
\hline 3 & Menu Daftar & $\begin{array}{l}\text { Tampilan ini berisikan form pendaftran untuk } \\
\text { mengisi biodata peserta pendaftar seminar. }\end{array}$ \\
\hline 4 & Menu Membuat Qr Code & $\begin{array}{l}\text { Tampilan ini berisikan form untuk membaut QR } \\
\text { Code yang di dalamnya terdapat pilihan free texs } \\
\text { dan no hendphone untuk di jadikan QR Code. }\end{array}$ \\
\hline 5 & Menu Selesai & Menu ini untuk keluar dari Websate. \\
\hline 6 & Menu Home admin & $\begin{array}{l}\text { Menu ini menampilkan menu-menu yang di kelola } \\
\text { oleh admin seperti menu katagori, peserta, QR } \\
\text { Code, absensi, rekap, Logout. }\end{array}$ \\
\hline 7 & Menu katagori & $\begin{array}{l}\text { Menu ini berfungsi untuk mengelola data nama } \\
\text { katagori peserta. }\end{array}$ \\
\hline 8 & Menu Peserta & $\begin{array}{l}\text { Menu ini untuk mengola data peserta seperti } \\
\text { mengimput data peserta,edit dan hapus. }\end{array}$ \\
\hline 9 & Menu QR Code & $\begin{array}{l}\text { Menu ini untuk mescaen QR Code yang di bawa } \\
\text { oleh peserta seminar. } \\
\text { Menu ini untuk mengelola absen peserta seminar. }\end{array}$ \\
\hline 10 & Menu Absen & \\
\hline & &
\end{tabular}




\begin{tabular}{|c|l|l|}
\hline No & \multicolumn{1}{|c|}{ Nama Halaman } & \multicolumn{1}{c|}{ Penjelasan } \\
\hline 11 & Menu Rekap & $\begin{array}{l}\text { Menu ini menampilkan rekap data-data peserta } \\
\text { yang mengikuti seminar baik itu dari pelajar } \\
\text { maupun daru umum. }\end{array}$ \\
\hline 12 & Menu Logout & Menu ini untuk keluar dari website. \\
\hline
\end{tabular}

\subsection{Kebutuhan Lingkungan Sistem untuk Perancangan}

Perangkat lunak yang dibutuhkan dalam pembanguna aplikasi registrasi seminar berbasis web menggunakan QR Code adalah sebagai berikut :

a. Sistem Operasi

Sistem operasi yang digunakan yaitu MS Windows 10 .

b. Bahasa Pemograman

Bahasa pemograman yang digunakan pada perankat lunak ini adalah bahasa pemograman PHP.

c. Basis Data

Basis data yang digunakan yaitu My SQL, bahasa dasar untuk mengakses basis data.

d. Web Browser

Web server yang dapat digunakan diantaranya Mozila Firefox, Google Crome.

Perangkat keras yang dibutuhkan dalam pembanguna aplikasi registrasi seminar berbasis web menggunakan QR Code adalah sebagai berikut :

Tabel 2. Spesifikasi Perangkat

\begin{tabular}{|c|l|l|}
\hline No & \multicolumn{1}{|c|}{ Perangkat Keras } & \multicolumn{1}{c|}{ Nama dan Jenis } \\
\hline 1. & Monitor & LED 14 Inchi \\
\hline 2. & Processor & Intel i3 \\
\hline 3. & RAM & 4 GB \\
\hline 4. & Hardisk & 500 GB SATA \\
\hline 5. & Printer + Scanner & Ink Jet dan Scanner \\
\hline
\end{tabular}

\subsection{Aktor pada Aplikasi}

Langkah pertama dalam pembangunan aplikasi registrasi seminar berbasis web menggunaan QR Code adalah menentukan aktor. Aktor adalah seseorang atau sesuatu yang menyatakan suatu peran dan menggambarkan pemakai perangkat lunak aplikasi. Dengan adanya aktor maka memberikan suatu gambaran yang jelas tentang apa yang harus dikerjakan oleh perangkat lunak pada saat berinteraksi dengan Use case yang berkaitan.

Tabel 3. Penentuan Aktor Use case

\begin{tabular}{|c|l|}
\hline Aktor & \multicolumn{1}{c|}{ Penjelasan } \\
\hline \multirow{3}{*}{ Admin } & $\begin{array}{l}\text { Admin atau administrator merupakan pihak yang bertanggungjawab } \\
\text { untuk mengelola data biodata peserta yang mengikuti seminar secara } \\
\text { keseluruhan.yang menjadi admin adalah salah satu panitia pelaksanaan } \\
\text { seminar. Administrator juga mengelola pelayanan secara online dimana } \\
\text { administrator menerima data pelayanan secara online untuk pendaftaran }\end{array}$ \\
\hline
\end{tabular}




\begin{tabular}{|c|l|}
\hline Aktor & \multicolumn{1}{|c|}{ Penjelasan } \\
\hline & $\begin{array}{l}\text { dan juga melayani pendaftaran di tempat seminar di tempat secara } \\
\text { langsung. Biodata peserta yang nantinya akan di rekap untuk pengisian } \\
\text { biodata pada sertifikat seminar. }\end{array}$ \\
\hline Peserta & $\begin{array}{l}\text { Peserta merupakan pihak yang langsung berinteraksi dengan sistem } \\
\text { untuk mendaftar seminar. Yang menjadi user disini adalah umum, atau } \\
\text { mahasiswa. }\end{array}$ \\
\hline
\end{tabular}

\subsection{Use Case}

Dalam hal ini, dimulai dengan membuat formulasi model yang mampu menterjemahkan kebutuhan fungsional informasi tersebut. Berikut ini adalah formulasi model dalam bentuk Use Case Diagram yang akan dikembangkan pada aplikasi registrasi seminar berbasis web dengan menggunakan QR Code.

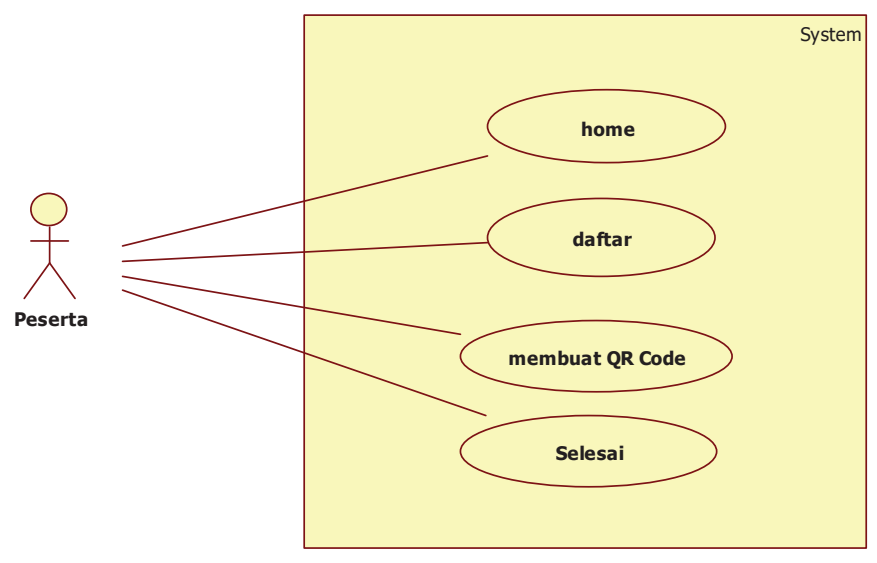

Gambar 4. Use Case Peserta

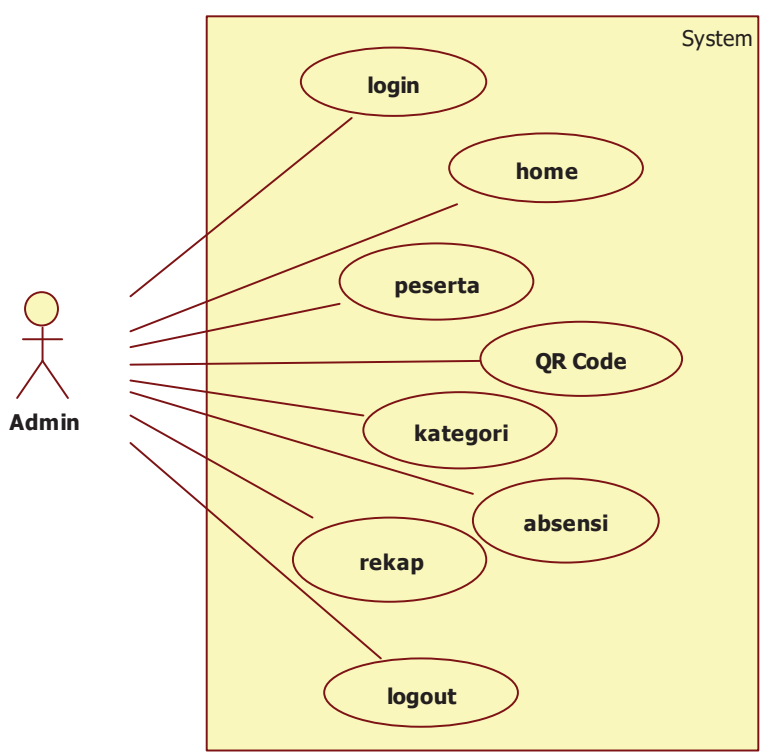

Gambar 5. Use Case Admin 


\subsection{Class Diagram}

Kelas (Class) adalah sebuah spesifikasi yang jika diinstansiasi akan menghasilkan sebuah objek dan merupakan inti dari pengembangan dan desain berorientasi objek. Kelas menggambarkan keadaan (atribut/properti) suatu sistem, sekaligus menawarkan layanan untuk memanipulasi keadaan tersebut (metoda/fungsi). Dari class diagram hubungan antar kelas yang satu dengan yang lain. Dimana hubungan antar kelas tersebut saling berhubungan antara yang satu dengan yang lainnya. Hubungan antar kelas diatas yaitu hubungungan kelas peserta berhubungan dengan kelas home, daftar dan buat barcode sedangkan kelas admin berhubungan dengan kelas home, kategori, QR Code, absensi, dan rekap.

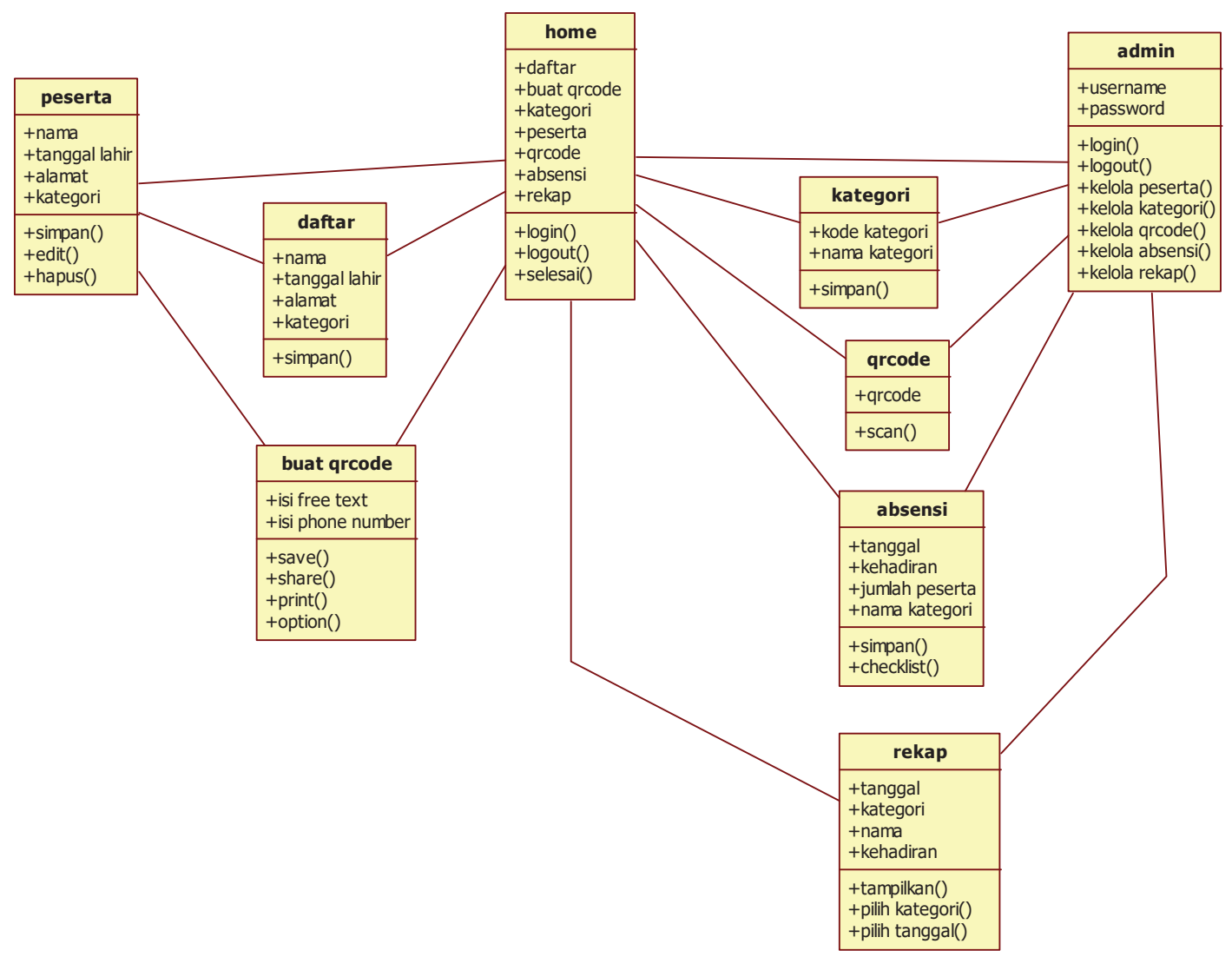

Gambar 6. Class Diagram Aplikasi Registrasi Seminar

\subsection{Tabel Basis Data}

Pada daftar tabel basis data dilakukan perancangan tabel-tabel yang akan digunakan pada basis data. Tabel terdiri kumpulan data tentang subjek tertentu yang disusun dalam bentuk kolom dan baris. Tabel merupakan komponen utama dari sebuah basis data. Adapun tabel-tabel yang digunakan sebagai berikut: 
1. Tabel Pendaftaran

Tabel 4. Pendaftaran

\begin{tabular}{|l|l|l|l|}
\hline Nama Field & Tipe Data & Ukuran Field & Keterangan \\
\hline No & Int & & Primary key \\
\hline Nama & Varchar & 20 & \\
\hline Tanggal Lahir & Date & & \\
\hline Alamat & Varchar & 50 & \\
\hline Kategori & Varchar & 30 & \\
\hline
\end{tabular}

2. Tabel Buat QR Code

Tabel 5. Buat QRCode

\begin{tabular}{|l|l|l|l|}
\hline Nama Field & Tipe Data & Ukuran Field & Keterangan \\
\hline Id & Int & & Primary key \\
\hline tipe & Varchar & 20 & \\
\hline Url_Foto & Varchar & 20 & \\
\hline
\end{tabular}

3. Tabel Kategori

Tabel 6. Kategori

\begin{tabular}{|l|l|l|l|}
\hline Nama Field & Tipe Data & Ukuran Field & Keterangan \\
\hline Kode Kategori & Int & & Primary key \\
\hline Nama Kategori & Varchar & 25 & \\
\hline
\end{tabular}

4. Tabel Peserta

Tabel 7. Peserta

\begin{tabular}{|l|l|l|l|}
\hline Nama Field & Tipe Data & Ukuran Field & Keterangan \\
\hline No & Int & & Primary key \\
\hline Nama & Varchar & 20 & \\
\hline Tanggal Lahir & Date & & \\
\hline Alamat & Varchar & 50 & \\
\hline Kategori & Varchar & 30 & \\
\hline
\end{tabular}

5. Tabel Qrcode

Tabel 8. QRCode

\begin{tabular}{|l|l|l|l|}
\hline Nama Field & Tipe Data & Ukuran Field & Keterangan \\
\hline Id & Int & & Primary key \\
\hline Nomor Qrcode & Int & & \\
\hline
\end{tabular}


6. Tabel Absensi

Tabel 9. Absensi

\begin{tabular}{|l|l|l|l|}
\hline Nama Field & Tipe Data & Ukuran Field & Keterangan \\
\hline No & Int & & Primary key \\
\hline Nama Kategori & Varchar & 50 & \\
\hline Jumlah Peserta & Text & 20 & \\
\hline Nama & Varchar & 50 & \\
\hline Kehadiran & Varchar & 20 & \\
\hline
\end{tabular}

7. Tabel Rekap

Tabel 10. Rekap

\begin{tabular}{|l|l|l|l|}
\hline Nama Field & Tipe Data & Ukuran Field & Keterangan \\
\hline No & Int & & Primary key \\
\hline Nama & Varchar & 30 & \\
\hline Kehadiran & Int & & \\
\hline
\end{tabular}

\subsection{Antarmuka}

Tahap perancangan antarmuka digunakan untuk menggambarkan tampilan yang akan dibuat.

Antarmuka ini merupakan halaman utama pada saat pertama membuka aplikasi registrasi seminar berbasis web dimana admin masuk ke menu login dan peserta yang mau mendaftar seminar ke menu daftar.

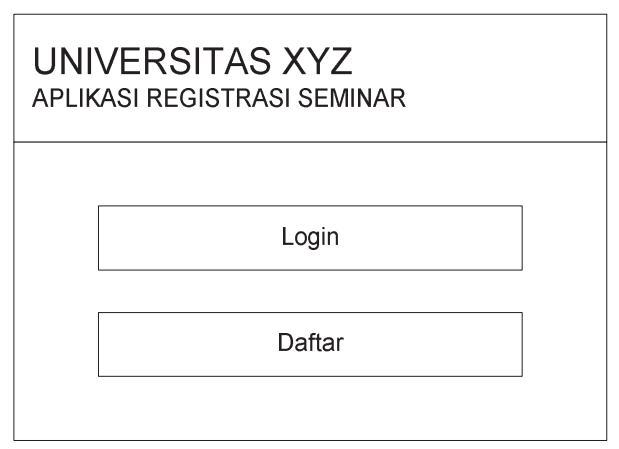

Gambar 7. Antarmuka Halaman Utama Aplikasi Registrasi Seminar

Antarmuka home ini merupakan rancangan yang menampilkan di dalam aplikasi registrasi seminar berbasis web yang di dalamnya berisi informasi tahapan registrasi. 


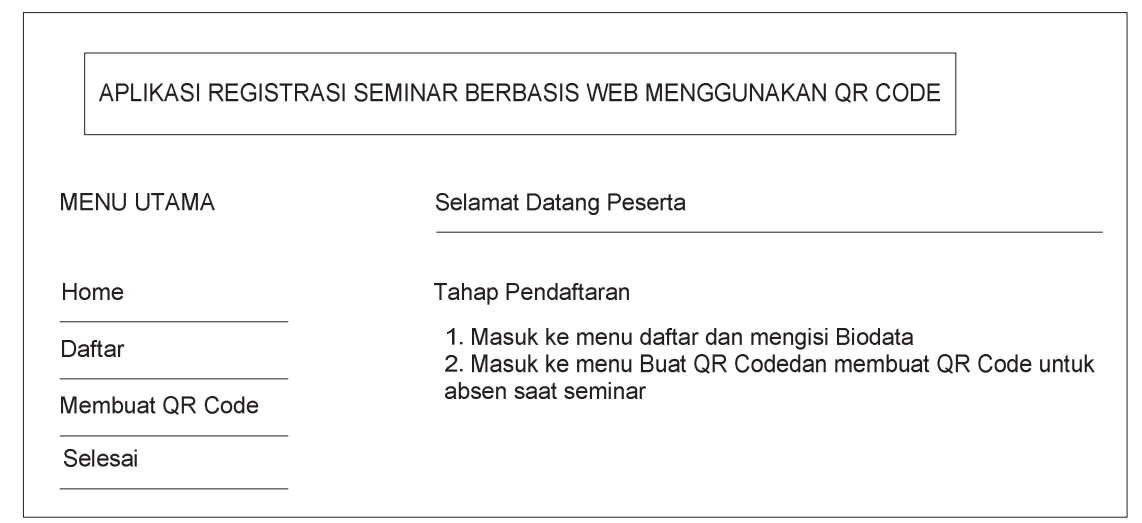

Gambar 8. Antarmuka Halaman Home Aplikasi Registrasi Seminar

Antarmuka daftar peserta ini merupakan rancangan yang menampilkan hamalan biodata yang harus di isi secara lengkap oleh peserta yang akan mengikuti seminar.

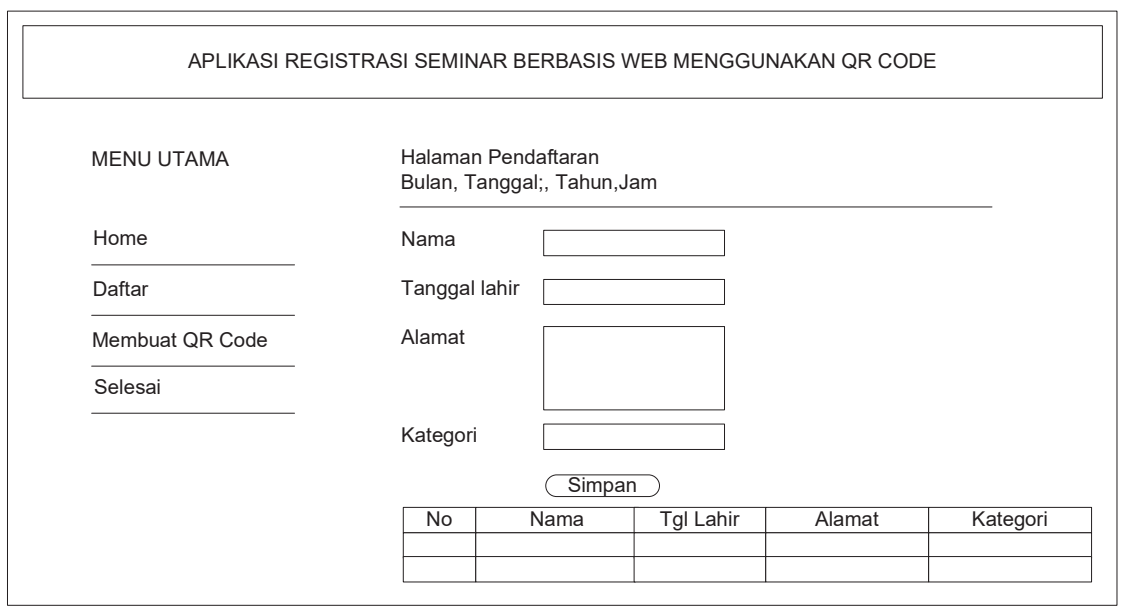

Gambar 9. Antarmuka Halaman Pendaftaran Aplikasi Registrasi Seminar

Antarmuka membuat QR Code peserta ini merupakan rancangan yang menampilkan data apa yang akan di jadikan menjadi QR Code oleh peserta diantaranya free text dan no handphone bila peserta sudah memilih data apa yang akan di jadikan QR Code peserta dapat di save,share dan print QR Code tersebut dan membawanya untuk pendaftaran ulang pada saat seminar. 


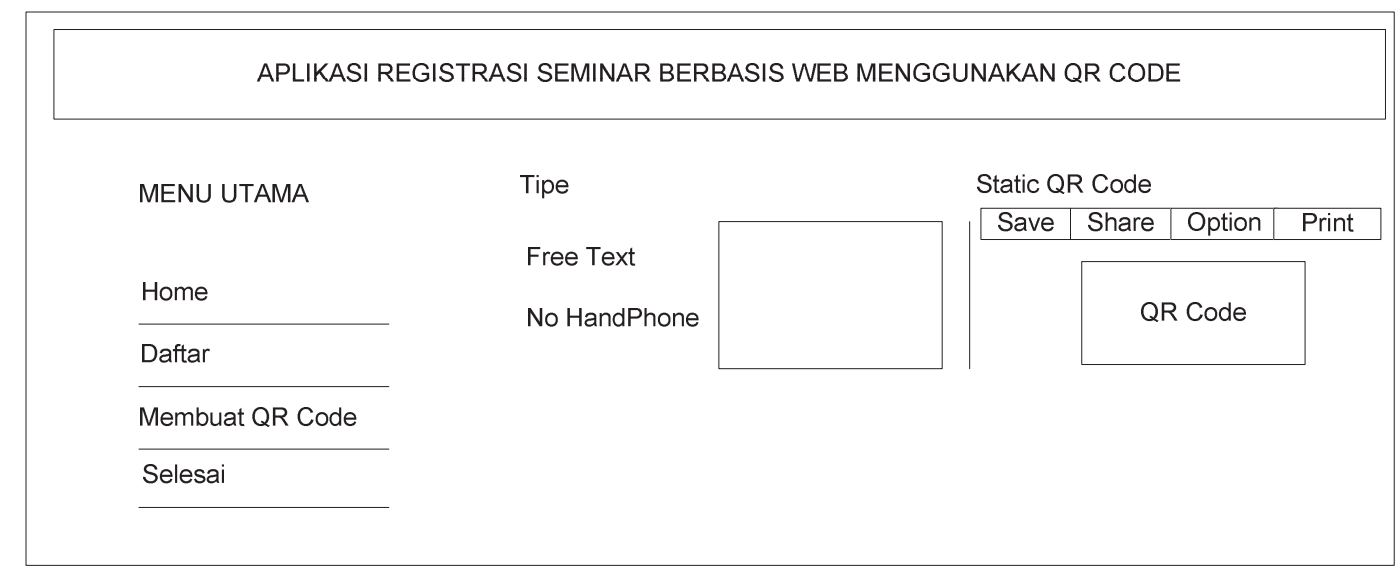

Gambar 10. Antarmuka Halaman Pendaftaran Aplikasi Registrasi Seminar

Antarmuka home pada tampilan admin ini merupakan rancangan yang menampilkan halaman home pada saat admin sudah melakukan login.

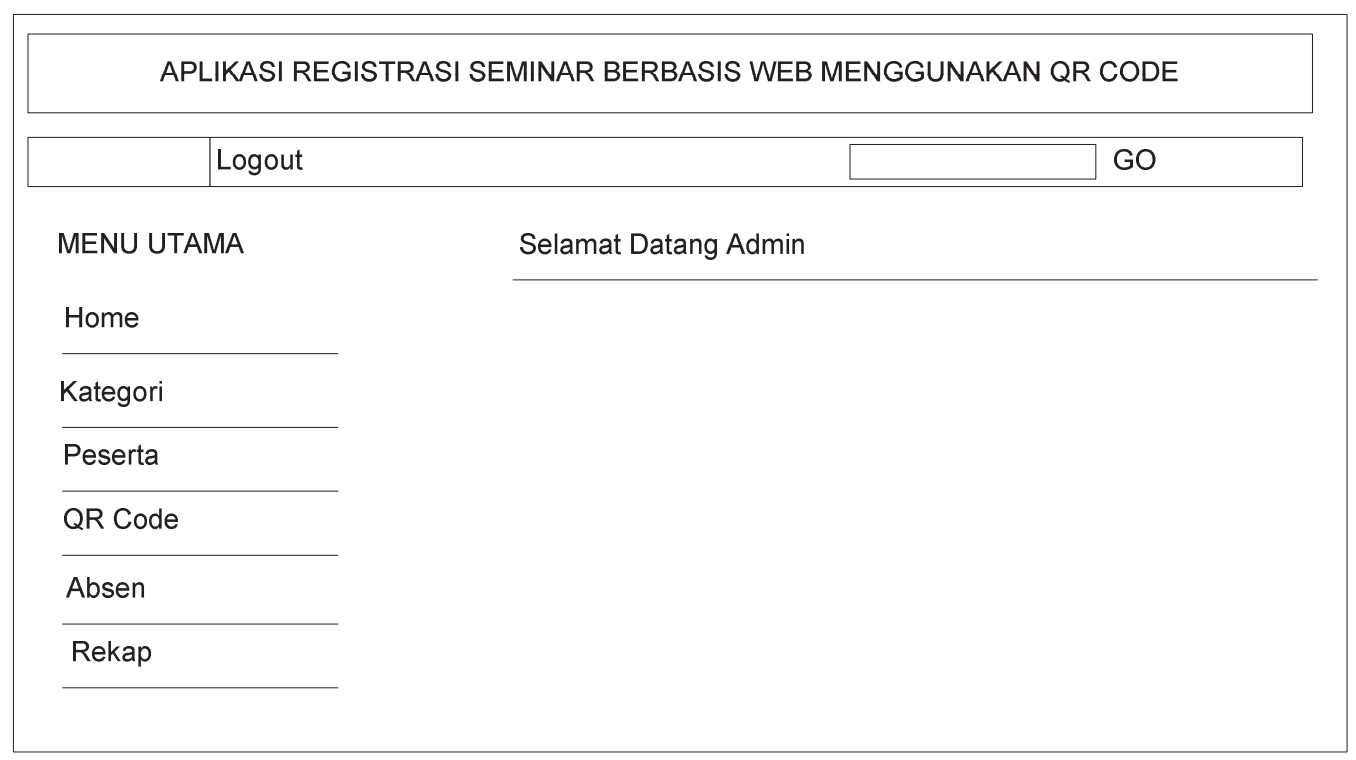

Gambar 11. Antarmuka Halaman Home Admin Aplikasi Registrasi Seminar

Antarmuka katagori pada tampilan admin ini merupakan rancangan yang menampilkan katagori peserta yang mengikuti seminar yaiut katagori pelajar dan umum. 


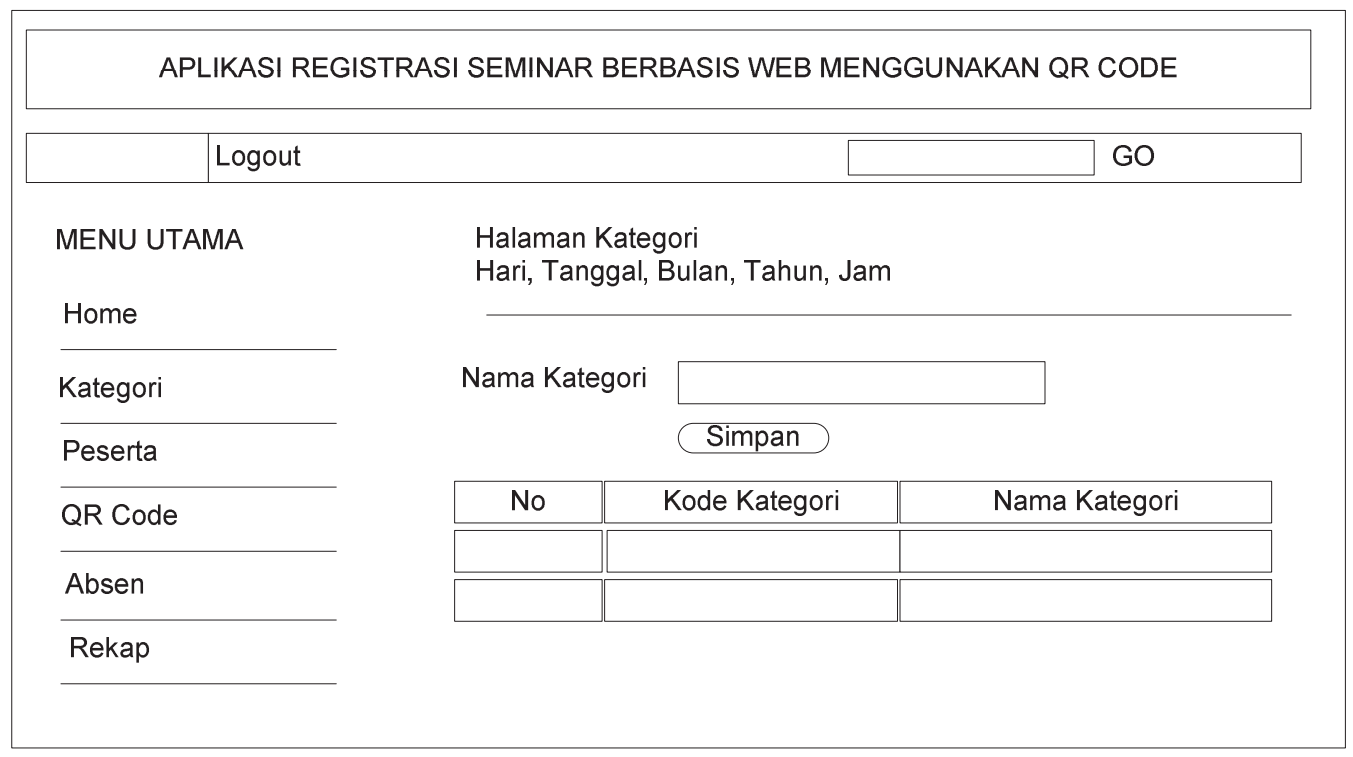

Gambar 12. Antarmuka Halaman Kategori Admin Aplikasi Registrasi Seminar

Antarmuka Peserta pada tampilan admin ini merupakan rancangan yang menampilkan absen peserta yang mengikuti seminar. Di dalam rancangan absensi ini admin dapat mengelola absen seperti tombol simpan, tombol edit dan tombol hapus.

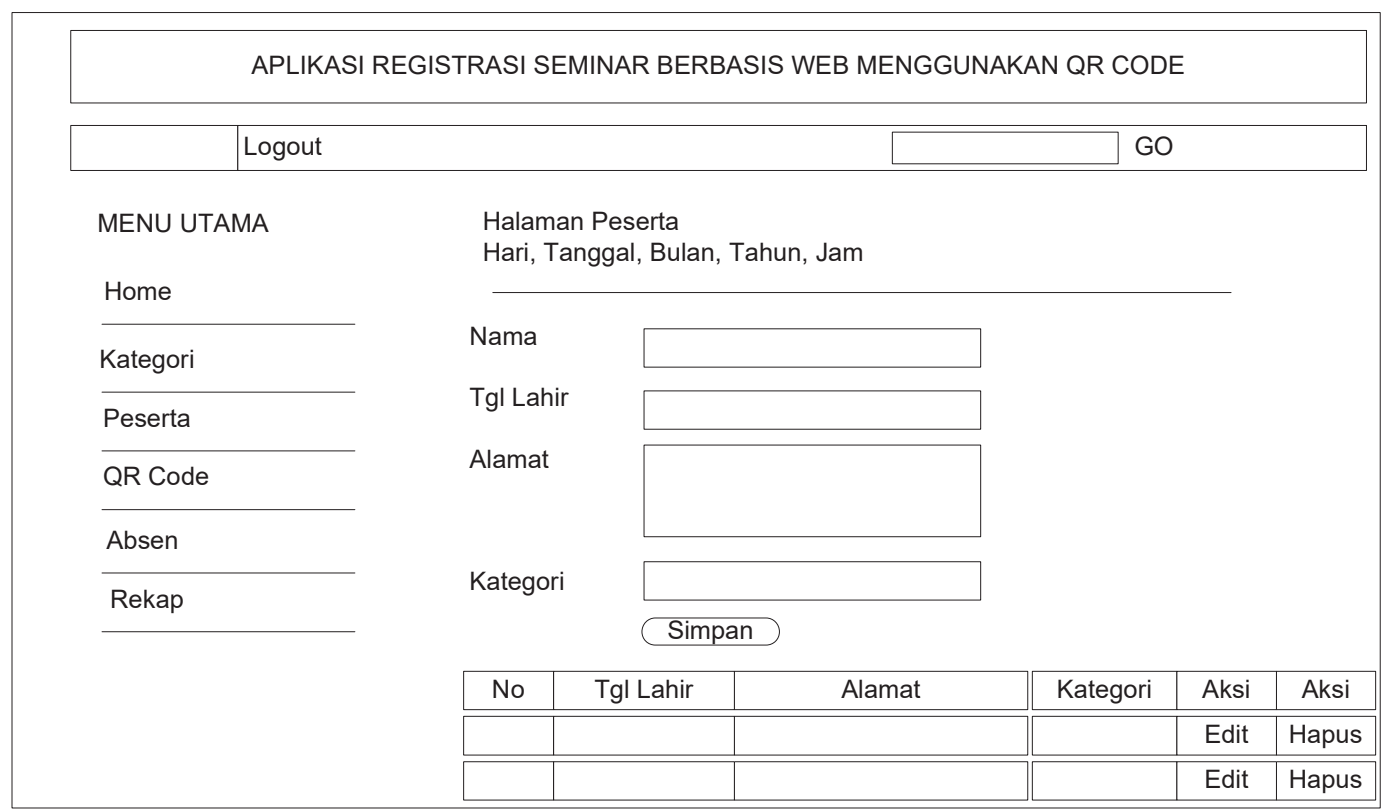

Gambar 13. Antarmuka Halaman Pesertai Admin Aplikasi Registrasi Seminar

Antarmuka QR Code pada tampilan Admin ini merupakan rancangan yang menampilkan untuk melakukan scan QR Code yang harus di bawa oleh peserta untuk melakukan registrasi ulang pada saa seminar. 


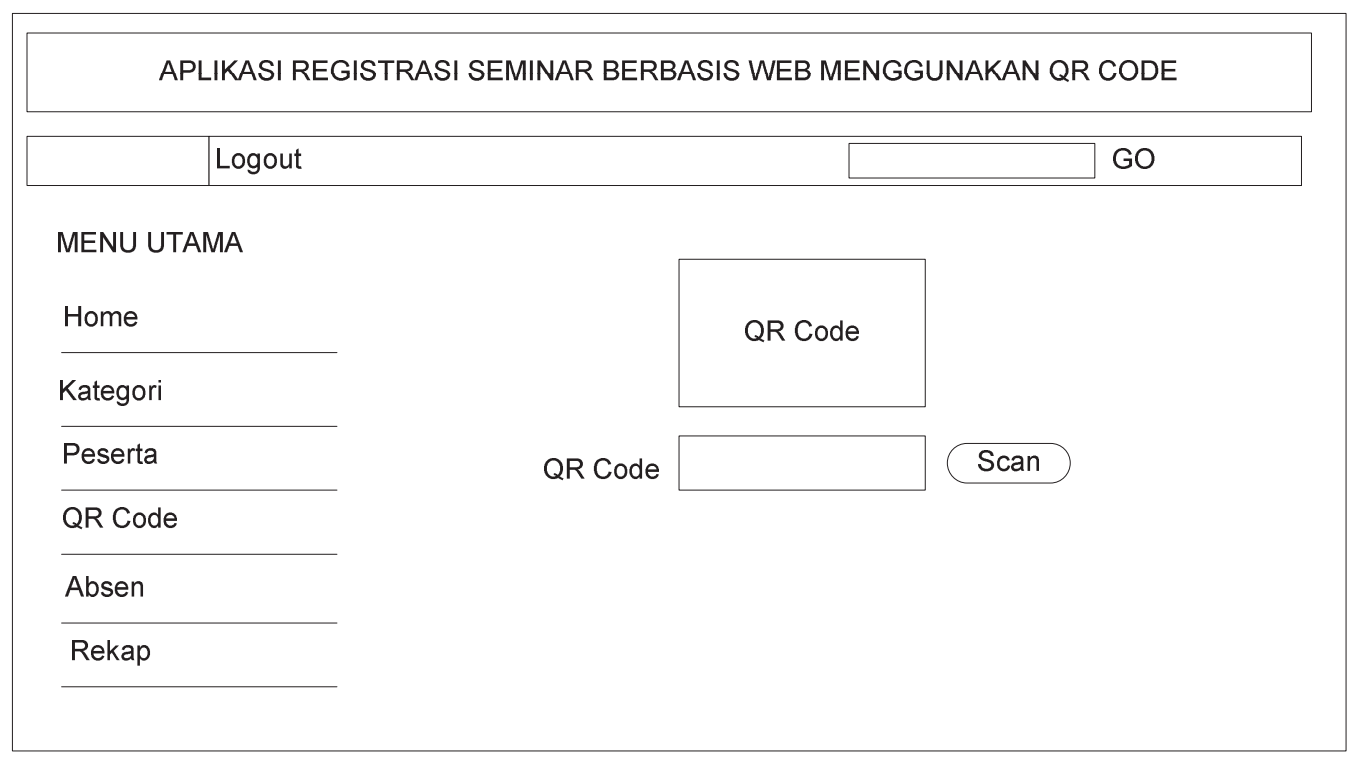

Gambar 14. Antarmuka Halaman QR Code Admin Aplikasi Registrasi Seminar Antarmuka absen pada tampilan admin ini merupakan rancangan yang menampilkan data peserta seminar untuk di lakukan absensi secara manual.

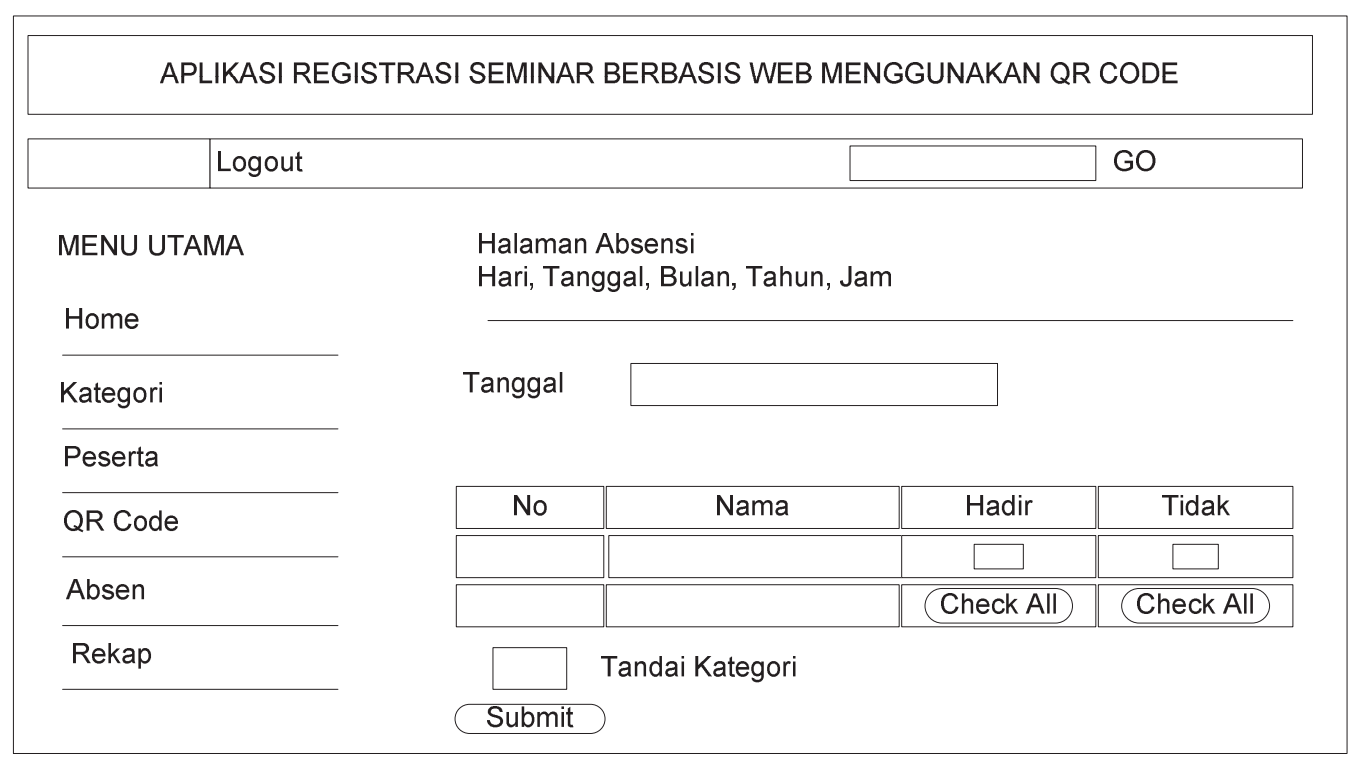

Gambar 15. Antarmuka Halaman Absensi Admin Aplikasi Registrasi Seminar

Antarmuka rekap pada tampilan admin ini merupakan rancangan yang menampilkan rekap absen semua peserta yang telah mengikuti seminar baik dari pelajar maupun dari umum untuk mengetahui berapa jumlah semua yang mengikuti seminar. 


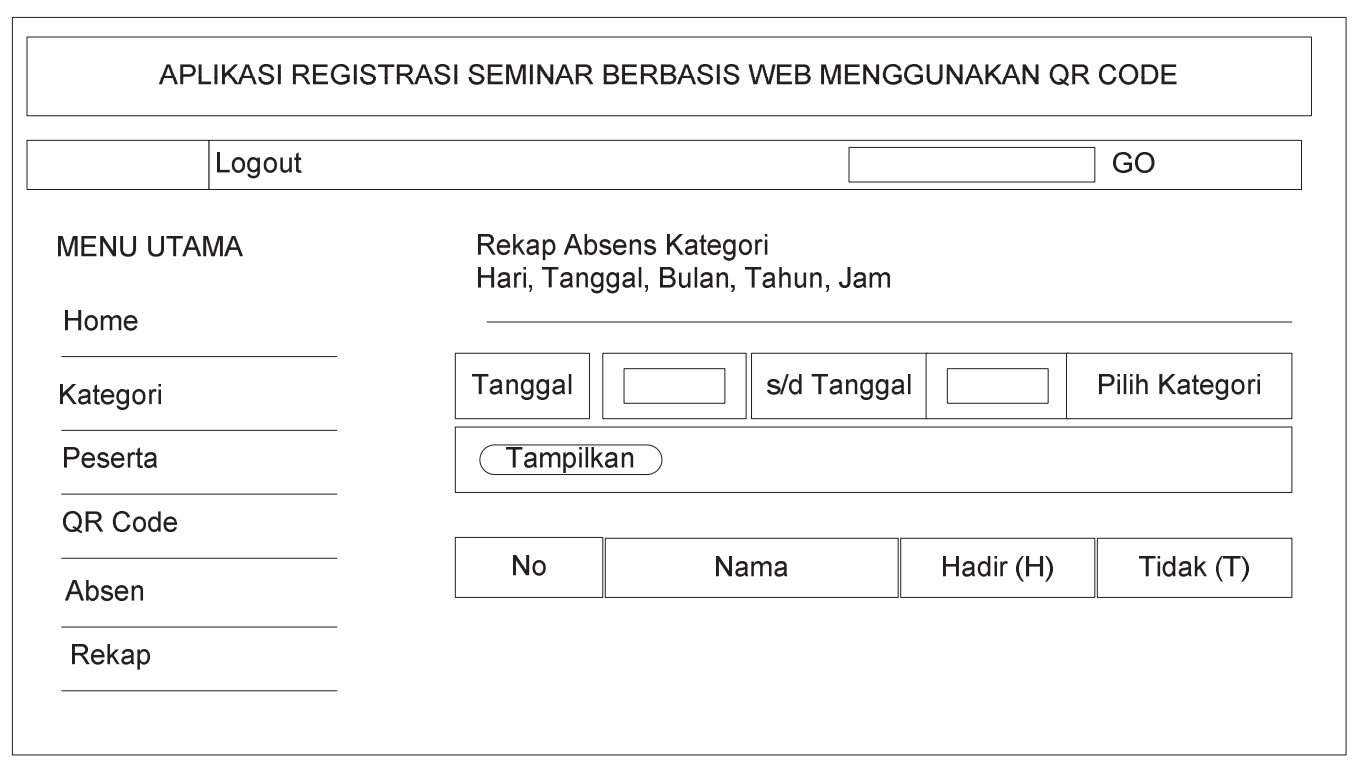

Gambar 16. Antarmuka Halaman Rekap Admin Aplikasi Registrasi Seminar

\subsection{Pengujian Aplikasi}

Pada tahap ini pengujian bertujuan untuk mengetahui apakah fitur-fitur yang terdapat dalam sistem pendaftaran seminar tersebut berjalan sesuai dengan rencana. Metode yang digunakan dalam penelitian ini adalah metode blackbox. Pengujian ini nantinya akan dilakukan oleh organisasi yang akan melakukan seminar.

\section{Hasil dan Pembahasan}

Hasil yang dicapai dari sistem ini menghasilkan sebuah aplikasi registrasi seminar berbasis web dengan menggunakan QR Code yang berisi data client, data pengguna, data seminar, data kehadiran, berdasarkan seminar yang diikuti oleh peserta, hak akses sesuai dengan status yang database dimana admin dapat masuk ke halaman utama dan halaman admin, client dapat masuk ke halaman utama dan halaman client serta user dapat masuk ke halaman utama dan halaman user. Halaman awal merupakan halaman utama yang berisi seminar yang bisa diikuti oleh seminar dari list seminar tersebut lalu melakukan registrasi untuk mengikuti seminar yang ingin diikuti.

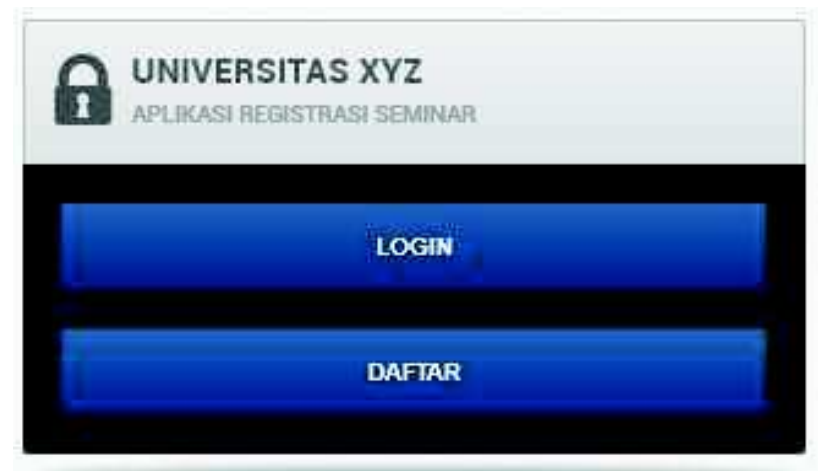

Gambar 17. Halaman Login Aplikasi Registrasi Seminar 


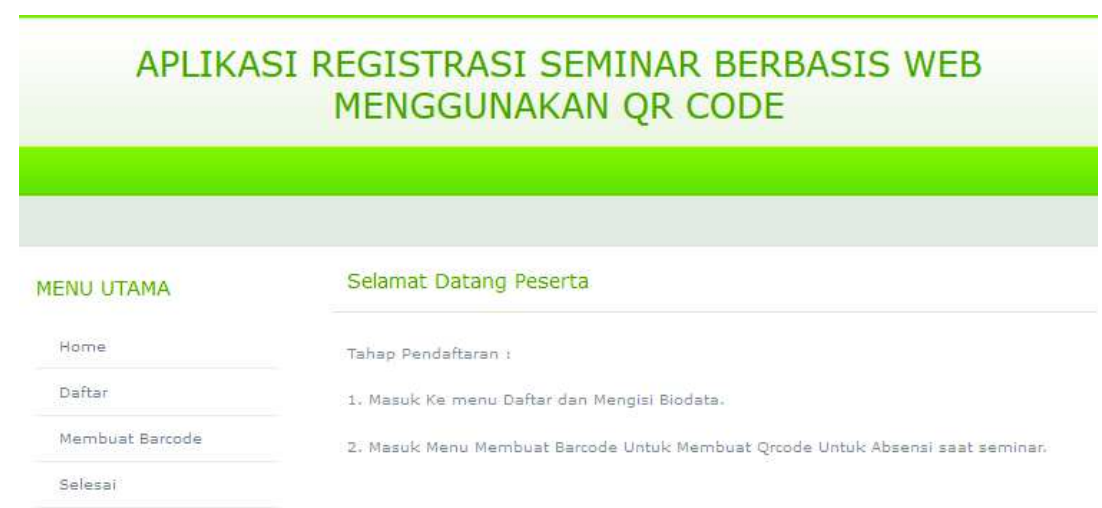

Gambar 18. Halaman Home Peserta Aplikasi Registrasi Seminar

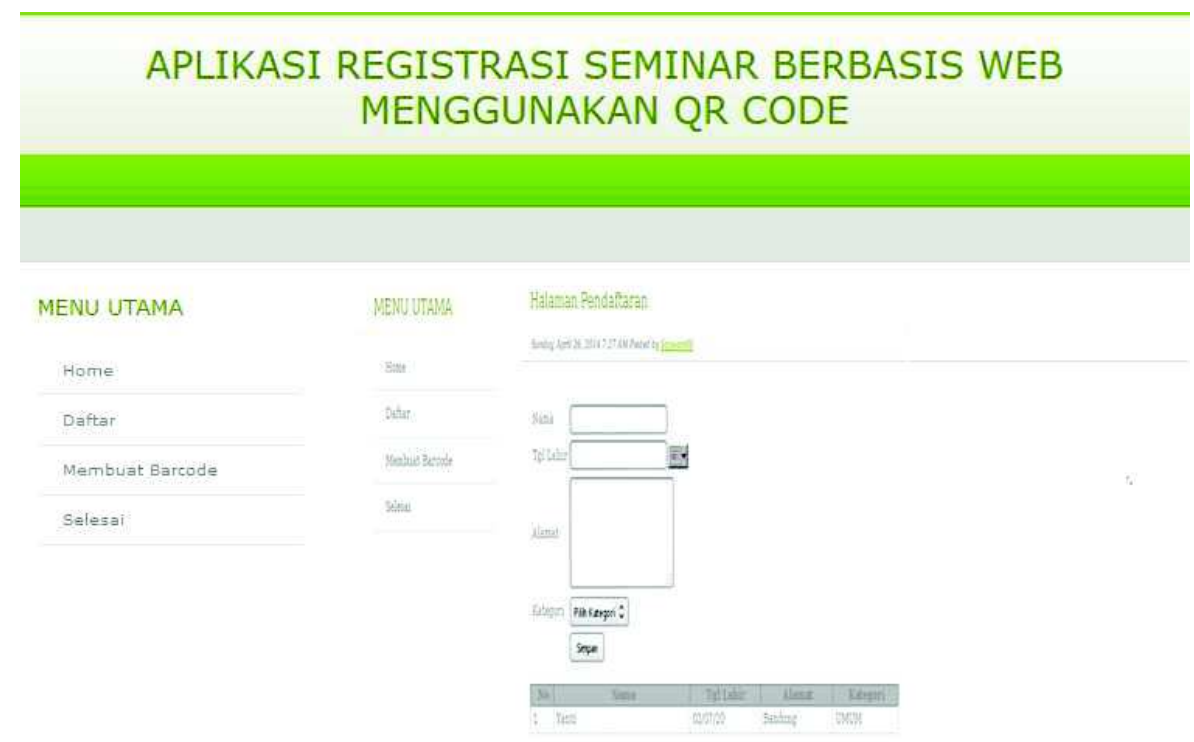

Gambar 19. Halaman Pendaftaran Peserta Aplikasi Registrasi Seminar

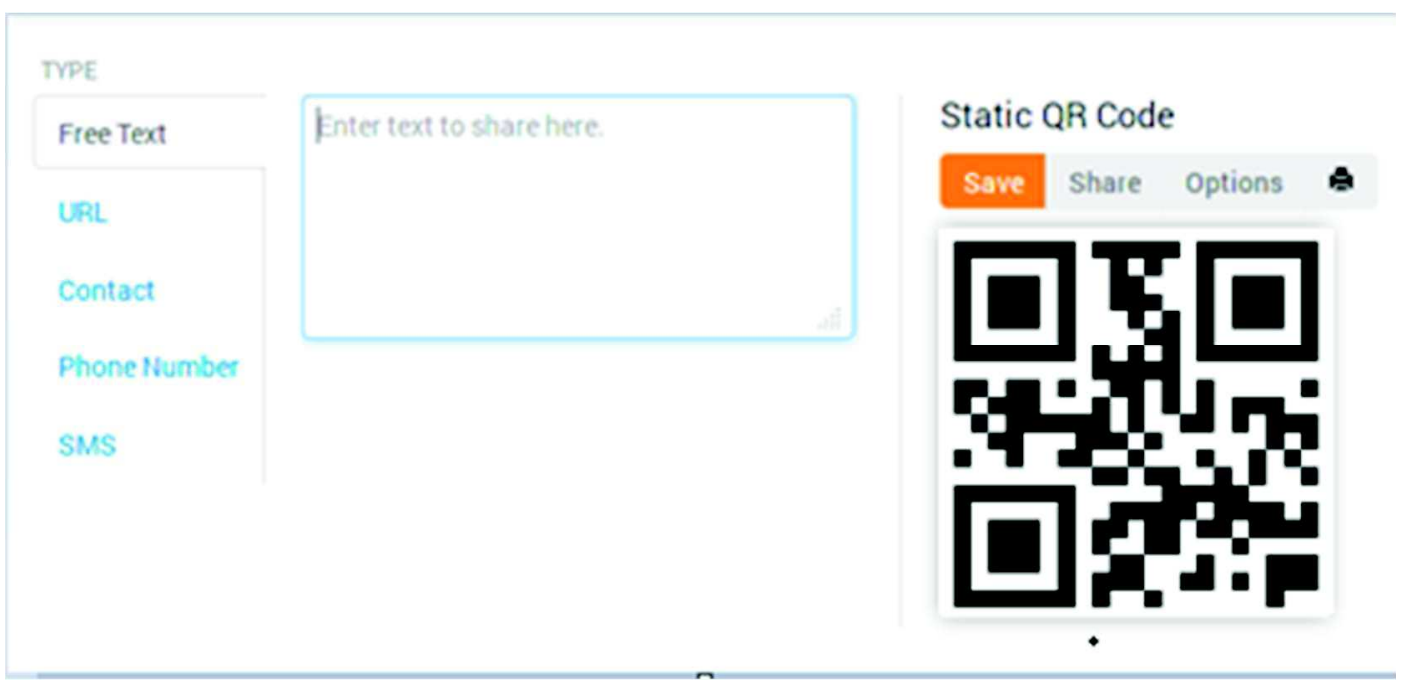

Gambar 20. Halaman Membuat QR Code Aplikasi Registrasi Seminar 


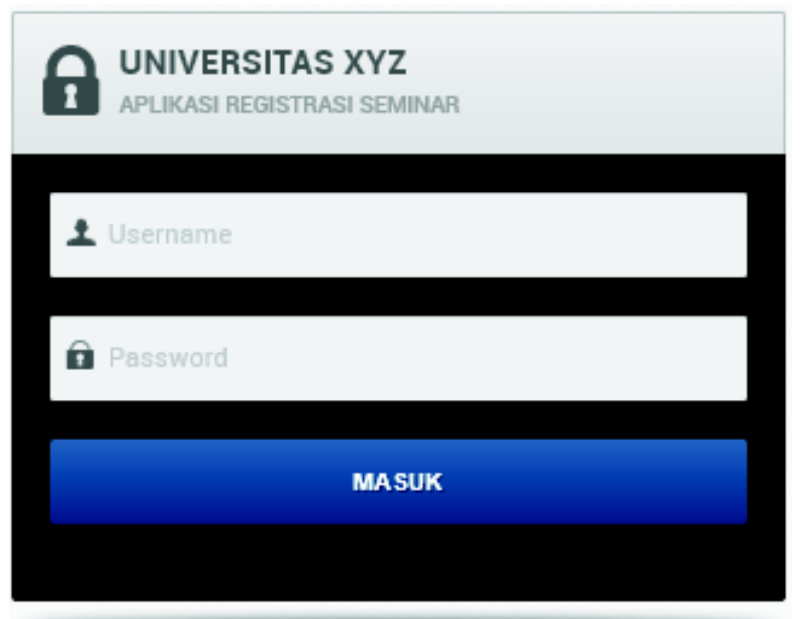

Gambar 21. Halaman Login Admin Aplikasi Registrasi Seminar

\section{APLIKASI REGISTRASI SEMINAR BERBASIS WEB MENGGUNAKAN QR CODE}

MENU UTAMA

\begin{tabular}{l} 
Home \\
Kategori \\
\hline Peserta \\
\hline QRcode \\
\hline Absensi \\
\hline Rekap
\end{tabular}

Selamat Datang Peserta

Tahap Pendaftaran :

1. Masuk Ke menu Daftar dan Mengisi Biodata.

2. Masuk Menu Membuat Barcode Untuk Membuat Qrcode Untuk Absensi saat seminar.

Gambar 22. Halaman Home Admin Aplikasi Registrasi Seminar

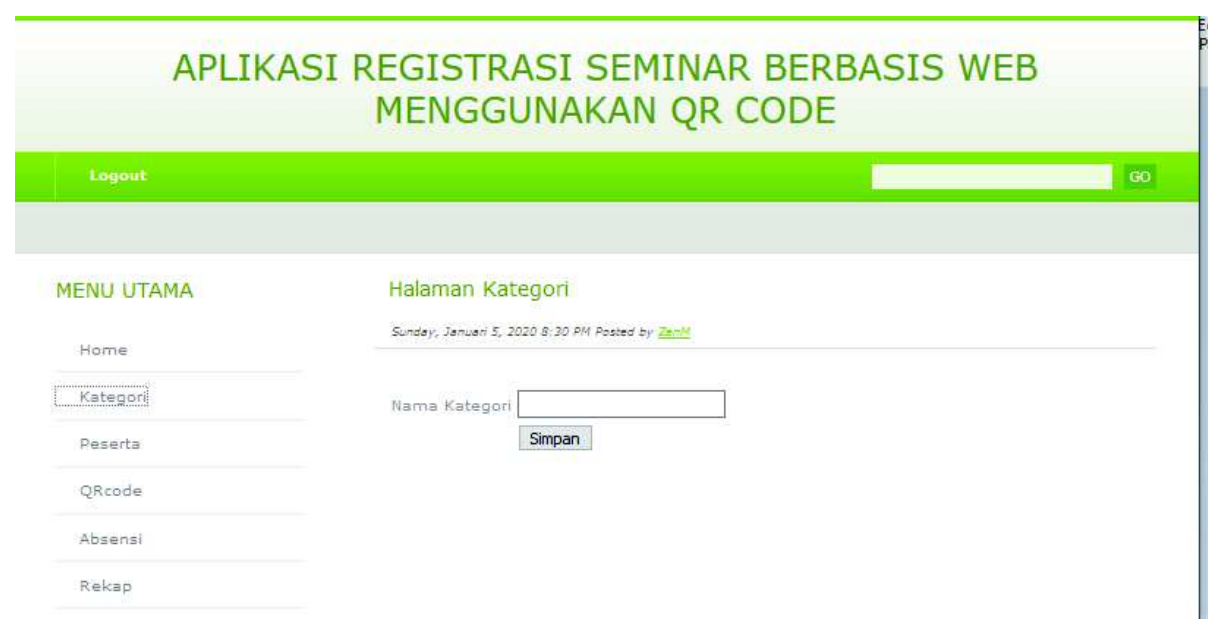

Gambar 23. Halaman Kategori Admin Aplikasi Registrasi Seminar 


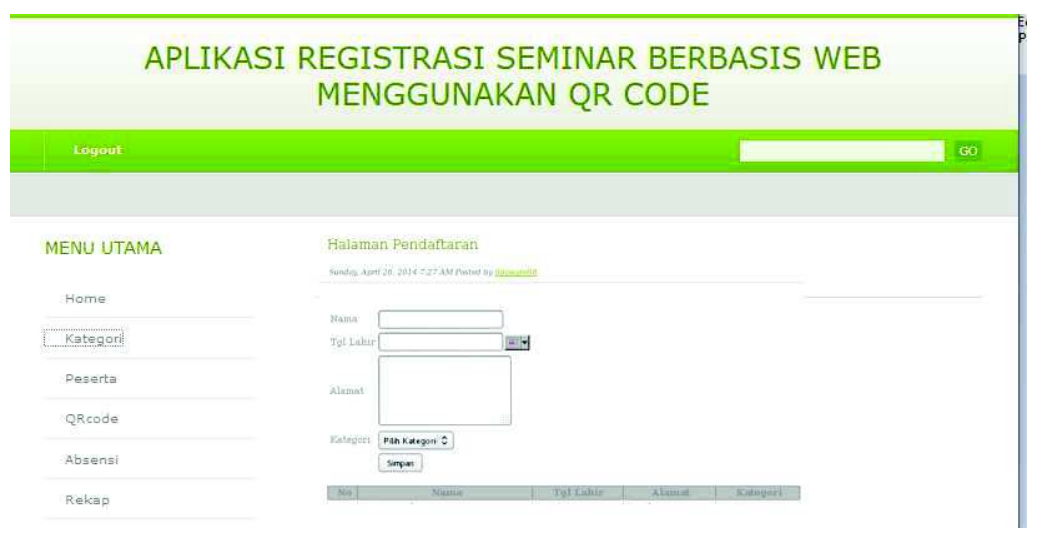

Gambar 24. Halaman Peserta Admin Aplikasi Registrasi Seminar

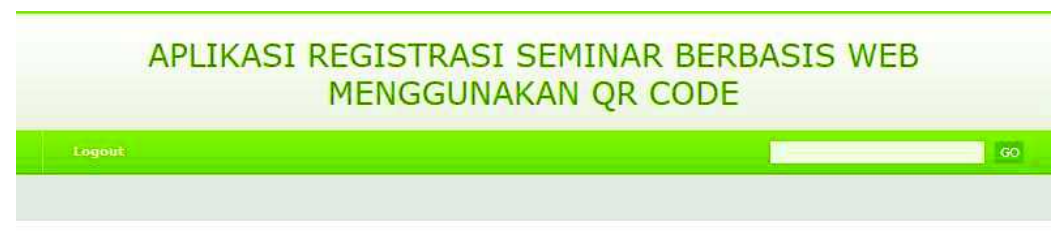

MENU UTAMA

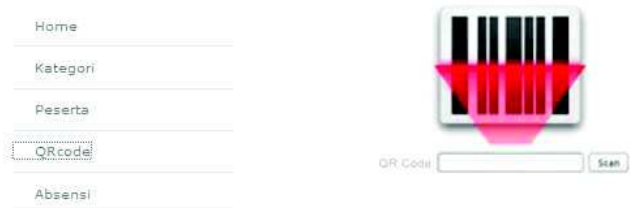

Gambar 25. Halaman QR Code Admin Aplikasi Registrasi Seminar

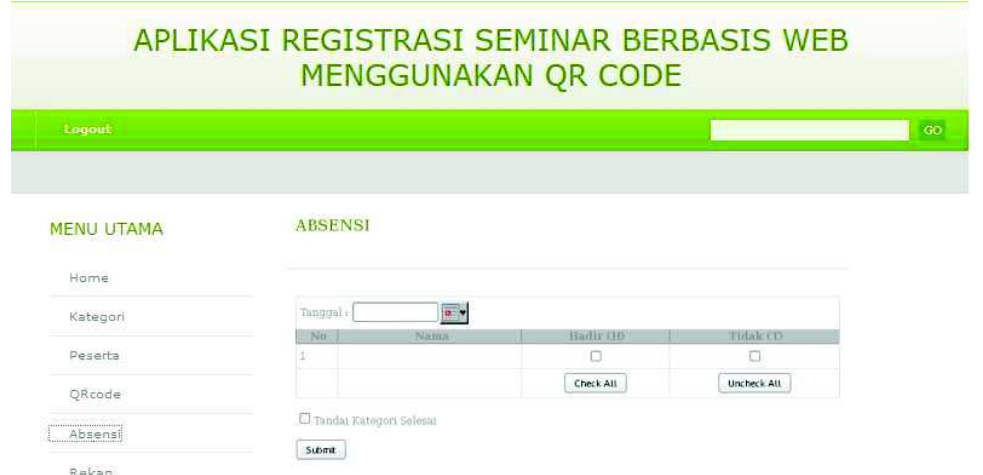

Gambar 26. Halaman Absensi Admin Aplikasi Registrasi Seminar

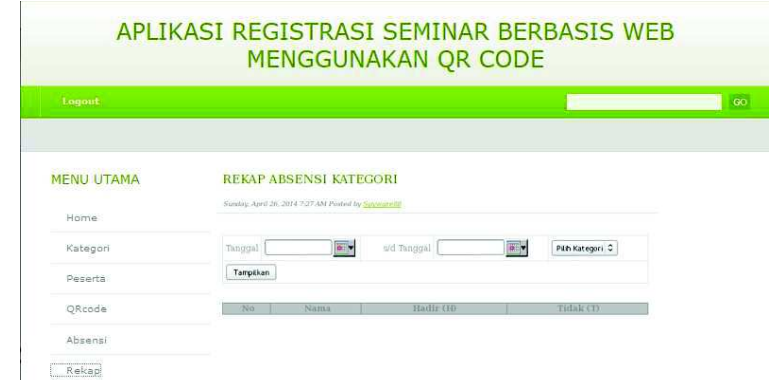

Gambar 27. Halaman Rekap Admin Aplikasi Registrasi Seminar 


\section{Pengujian}

Proses pengujian dilakukan untuk memastikan apakah sistem berjalan sesuai rencana awal yang telah dibuat atau tidak dan untuk mengetahui letak kesalahan yang ada pada sistem. Pengujian sistem ini dilakukan pada beberapa hal, yaitu :

\section{Pengujian Perangkat QR Code}

Tujuan dari perangkat ini adalah untuk mengetahui bagaimana kemampuan jangkauan dan batasan yang ada pada QR Code. Perangkat yang digunakan untuk membaca Qr Code adalah webcam. Tabel 1 merupakan hasil pengujian pada webcam.

Tabel 11. Pengujian Perangkat Keras QR Code

\begin{tabular}{|c|c|c|}
\hline No & Nama Pengujian & Hasil \\
\hline 1 & $\begin{array}{l}\text { Jarak terjauh membaca data QR } \\
\text { Code tanpa ada penghalang }\end{array}$ & $25-30 \mathrm{~cm}$ \\
\hline 2 & $\begin{array}{l}\text { Jarak terdekat membaca QR Code } \\
\text { pada tiket tanpa ada penghalang }\end{array}$ & $10-15 \mathrm{~cm}$ \\
\hline 3 & $\begin{array}{l}\text { Pencahayaan pada saat membaca } \\
\text { QR Code }\end{array}$ & $\begin{array}{l}\text { Proses membaca data QR Code } \\
\text { harus ada pencahayaan, jika tidak } \\
\text { data tidak bisa dibaca }\end{array}$ \\
\hline
\end{tabular}

\section{Pengujian Fungsi - Fungsi}

Tabel 12. Pengujian Fungsi- Fungsi

\begin{tabular}{|c|l|l|l|l|}
\hline No & \multicolumn{1}{|c|}{ Kelas Uji } & \multicolumn{1}{|c|}{ Butir Uji } & \multicolumn{1}{|c|}{$\begin{array}{c}\text { Jenis } \\
\text { Pengujian }\end{array}$} & \multicolumn{1}{|c|}{ Hasil } \\
\hline 1 & Home Peserta & $\begin{array}{l}\text { Menampilkan halaman } \\
\text { home peserta }\end{array}$ & Black Box & Sesuai \\
\hline 2 & $\begin{array}{l}\text { Pendaftaran } \\
\text { Peserta }\end{array}$ & $\begin{array}{l}\text { Menampilkan halaman } \\
\text { form pendaftaran peserta }\end{array}$ & Black Box & Sesuai \\
\hline 3 & $\begin{array}{l}\text { Buat Qrcode } \\
\text { peserta }\end{array}$ & $\begin{array}{l}\text { Menampilkan halaman } \\
\text { untuk buat qrcode } \\
\text { peserta }\end{array}$ & Black Box & Sesuai \\
\hline 4 & Selesai Peserta & $\begin{array}{l}\text { Keluar dari web } \\
\text { pendaftaran }\end{array}$ & Black Box & Sesuai \\
\hline 5 & Login Admin & $\begin{array}{l}\text { Login Admin mengakses } \\
\text { web }\end{array}$ & Black Box & Sesuai \\
\hline 7 & Kategori Admin & $\begin{array}{l}\text { Menampilkan halaman } \\
\text { untuk admin kelola data } \\
\text { kategori }\end{array}$ & Black Box & Sesuai \\
\hline 8 & Peserta Admin & $\begin{array}{l}\text { Menampilkan halaman } \\
\text { untuk admin kelola data } \\
\text { peserta }\end{array}$ & Black Box & Sesuai \\
\hline
\end{tabular}




\begin{tabular}{|c|l|l|l|l|}
\hline 9 & Qrcode Admin & Mescan Qrcode peserta & Black Box & Sesuai \\
\hline 10 & Absensi & $\begin{array}{l}\text { Menampilkan halaman } \\
\text { untuk admin kelola data } \\
\text { absensi secara manual }\end{array}$ & Black Box & Sesuai \\
\hline 11 & Rekap & $\begin{array}{l}\text { Menampilkan halaman } \\
\text { rekap absensi }\end{array}$ & Black Box & Sesuai \\
\hline
\end{tabular}

\section{Pengujian Kinerja}

Tabel 13. Pengujian Kinerja Data Masukan

\begin{tabular}{|c|c|c|c|}
\hline Data Masukan & Yang diharapkan & Pengamatan & $\begin{array}{c}\text { Hasil } \\
\text { Pengujian }\end{array}$ \\
\hline \multirow[t]{2}{*}{$\begin{array}{l}\text { Username dan } \\
\text { Password } \\
\text { Admin }\end{array}$} & \multirow[t]{2}{*}{$\begin{array}{l}\text { Username dan } \\
\text { password dicari di } \\
\text { tabel admin }\end{array}$} & $\begin{array}{l}\text { Jika username dan } \\
\text { password BENAR } \\
\text { maka masuk ke } \\
\text { halaman admin }\end{array}$ & Diterima \\
\hline & & $\begin{array}{l}\text { Jika username dan } \\
\text { password SALAH } \\
\text { maka tampil notif } \\
\text { login gagal }\end{array}$ & Diterima \\
\hline \multirow[t]{2}{*}{$\begin{array}{l}\text { Username dan } \\
\text { Password user }\end{array}$} & \multirow[t]{2}{*}{$\begin{array}{l}\text { Username dan } \\
\text { password dicari di } \\
\text { tabel user }\end{array}$} & $\begin{array}{l}\text { Jika username dan } \\
\text { password BENAR } \\
\text { maka masuk ke } \\
\text { halaman konfirmasi } \\
\text { pemberitahuan }\end{array}$ & Diterima \\
\hline & & $\begin{array}{l}\text { Jika username dan } \\
\text { password tidak valid } \\
\text { maka tampil notif } \\
\text { login gagal }\end{array}$ & Diterima \\
\hline $\begin{array}{l}\text { Input Data } \\
\text { Pendaftaran dan } \\
\text { absensi seminar }\end{array}$ & $\begin{array}{l}\text { Data pendaftaran } \\
\text { dan absensi } \\
\text { seminar terdiri } \\
\text { dari biodata, } \\
\text { kategori, qrcode } \\
\text { dan absensi }\end{array}$ & $\begin{array}{l}\text { Jika data terisi maka } \\
\text { akan tampil di } \\
\text { halaman web } \\
\text { pendaftaran dan } \\
\text { absensi seminar }\end{array}$ & Diterima \\
\hline $\begin{array}{l}\text { Edit Data } \\
\text { Pendaftaran }\end{array}$ & $\begin{array}{l}\text { Data pendaftaran } \\
\text { terganti dan } \\
\text { tersimpan pada } \\
\text { table masing - } \\
\text { masing fungsi }\end{array}$ & $\begin{array}{l}\text { Jika data terisi maka } \\
\text { akan di halaman kelola } \\
\text { pendaftaran admin } \\
\text { data tersebut berubah }\end{array}$ & Diterima \\
\hline $\begin{array}{l}\text { Hapus data } \\
\text { pendaftaran }\end{array}$ & $\begin{array}{l}\text { Data web terhapus } \\
\text { apabila di hapus } \\
\text { ke admin }\end{array}$ & $\begin{array}{l}\text { Jika data terhapus } \\
\text { maka data hilang pada } \\
\text { halaman web } \\
\text { pendaftaran dan } \\
\text { absensi seminar }\end{array}$ & Diterima \\
\hline
\end{tabular}




\begin{tabular}{|l|l|l|l|}
\hline Logout & $\begin{array}{l}\text { Merupakan akses } \\
\text { untuk keluar dari } \\
\text { web }\end{array}$ & $\begin{array}{l}\text { Admin Keluar dari } \\
\text { web }\end{array}$ & Diterima \\
\hline
\end{tabular}

\section{Kesimpulan}

Berdasarkan perancangan dan pembangunan aplikasi registrasi seminar berbasis web menggunakan QR Code dapat disimpulkan sebagai berikut : Aplikasi bekerja dengan baik sesuai dengan perancangan awal dan fitur-fitur yang ada pada aplikasi berfungsi, efisien serta membantu panitia dalam mengelola acara seminar, perangkat web camuntuk membaca QR Code juga berfungsi pada pencahayaan yang cukup terang dalam jarak 20$30 \mathrm{~cm}$. Hasil Pengujian menggunakan black box . juga sesuai tidak terjadi kesalahan, hal ini menunjukkan aplikasi efisien dan layak untuk diterapkan.

\section{Daftar Pustaka}

[1] Barjtya, S., Sharma, A., \& Rani, U. (2017). A detailed study of Software Development Life Cycle ( SDLC ) Models, International Journal Of Engineering And Computer Science, 6(7), 22097-22100).

[2] Hendry, R., Rahman, M. N. A., \& Seyal, A. H. (2017). Smart Attendance System Applying QR Code, 12th International Conference on Latest Trends in Engineering and Technology May 22-24, 2017 Kuala Lumpur (Malaysia), 1-5.

[3] J. Philippe Brossat. (2003), Software Requiremen Specification. Springer.

[4] Kaur, S. (2017). QR Code Security and Solution, International Journal of Engineering Science and Computing, 7(4), 10323-10325.

[5] Rosa A.S, M. Shalahuddin. (2015), Rekayasa Perangkat Lunak. Bandung. Informatika

[6] Talip, B. A. (2018). Mobile Attendance System Using Qr Codes Technology, Journal of Computing Technologies and Creative Content, 3(1), 1-3.

[7] Tiwari, S. (2016). An Introduction To QR Code Technology, International Conference on Information Technology, 4(3), 39-44. 